\title{
Industri Kreatif Unggulan Produk Kriya Pandan Mendukung Kawasan Ekowisata Pangandaran, Jawa Barat
}

\author{
Husen Hendriyana, I Nyoman Darma Putra, Yan yan Sunarya \\ FSRD Institut Seni Budaya Indonesia Bandung, Jl. Buah Batu No 212 Bandung, 40265 \\ Pusat Unggulan Pariwisata Universitas Udayana, Bali \\ FSRD Institut Teknologi Bandung \\ husenkriyadesain@gmail.com
}

\begin{abstract}
Pangandaran is known as one of many famous tourist destinations in West Java Province that possess potential beautiful natural marine resources. This coastal area which streches $91 \mathrm{~km}$ and has sloping steep rocky beaches. Grows overabundant pandan (pandanus tectorius) plants, however conditions are very damaged and there is no concern for good governance from the local government. This research aims to produce eminent products of craft in supporting tourism by increasing the natural resources potential and the local craftsmen resources from the surrounding areal environment. This article is result of applied research in a type of practice-led research with a focus on the creative industries of craft products that support tourism through the eco-design and eco-tourism approach. This research uses design-thinking method, with Participation Action Research (PAR) approach and the Hexa Helix system. The result is a eminent product prototypes and start up business of craft art creative industries that support eco-design and eco-tourism park.
\end{abstract}

Keywords: Creative Industry, Pangandaran Area, Pandan-based Craft, Ecotourism

\begin{abstract}
ABSTRAK
Pangandaran dikenal sebagai salah satu destinasi wisata di Provinsi Jawa Barat yang memiliki potensi alam laut yang indah. Wilayah pantai membentang sepanjang $91 \mathrm{~km}$ terdiri dari kawasan pantai pasir yang landai dan pantai berbatu curam. Di wilayah Pangandaran banyak ditumbuhi tanaman pandan (pandanus tectorius), namun kondisinya sangat rusak dan tidak ada kepeduliaan tata kelola yang baik dari pemerintah setempat. Penelitian ini bertujuan menghasilkan produkproduk seni kriya unggulan daerah untuk menunjang pariwisata dengan mengangkat potensi sumber daya alam dan sumber daya perajin dari lingkungan masyarakat setempat. Artikel ini merupakan salah satu hasil penelitian terapan jenis practice-led research dengan fokus industri kreatif produk seni kriya yang mendukung pariwisata melalui pendekatan eco-design dan ecotourism. Penelitian ini menggunakan metode design thinking, dengan pendekatan Participation Action Research (PAR) dan sistem Hexa Helix. Hasil dari penelitaian ini berupa prototipe produk unggulan dan terwujudnya start up-start up bisnis industri kreatif seni kriya pendukung ekowisata berbasis kawasan.
\end{abstract}

Kata Kunci: Industi Kreatif, Kawasan Pangandaran, Kriya Pandan, Ekowisata

\section{PENDAHULUAN}

Industri kreatif seni kriya dan desain berbasis pandan (pandanus tectorius) sangat potensial dan penting dikembangkan di Indonesia. Pertama, produk kerajinan berbahan baku pandan bersifat ramah lingkungan dan dapat mengurangi pemakaian sarana berbahan baku plastik yang sulit hancur. Kedua, Indonesia memiliki Sumber Daya Alam (SDA) hutan pandan 
yang luas. Ketiga, Indonesia memiliki Sumber Daya Manusia (SDM) yang terampil, baik karena otodidak berbasis kearifan lokal maupun mendapatkan pendidikan kerajinan di lembaga pendidikan formal. Keempat, penduduk Indonesia yang besar jumlahnya serta perkembangan pariwisata yang kian meningkat merupakan potensi pasar produk kerajinan anyamanan pandan. Dengan kata lain, demand akan produk seni kriya berbasis pandan cukup besar. Kelima, pemerintah memberikan perhatian serius pada industri kreatif dan usaha mikro kecil menengah atau UMKM (Wardhanie, 2018) dan (Suci, 2017).

Artikel ini mengkaji beberapa aspek kerajinan berbasis pandan sebagai industri kreatif dan mendukung pengembangan ekowisata di Pengandaraan, Jawa Barat. Pangandaraan memiliki pantai yang indah sekaligus lahan pandan yang subur-rimbun sebagai bahan baku anyaman dan daya tarik wisata yang indah dengan lanskap pandan. Selain menawarkan berbagai prototipe produk anyaman, artikel ini juga memberikan strategi pengembangan ekowisata Pangandaraan. Dengan kata lain, pandan diapresiasi dari dua segi, yaitu bahan baku kerajinan dan daya tarik wisata yang mesti dipertahankan (Hidayat, 2011; Dhalyana dan Adiwibowo 2013).

Artikel ini merupakan bagian dari penelitian jangka panjang, dengan road map penelitian yang meliputi pengembangan pengetahuan tentang kreativitas desain, produksi, teknologi tepat guna, distribusi, dan pemasaran, serta pengelolaan bahan baku berbasis kawasan wisata dengan memperhatikan potensi lingkungan alam setempat (desa wisata). Dalam hal ini, hutan pandan dimanfaatkan dari dua bidang utama, yaitu produksi seni kerajinan dengan pengutamaan pada eko-desain dan pengembangan daya tarik wisata berbasis ekowisata atau wisata alam dengan orientasi pandan dinikmati tetapi tetap lestari.

Pangandaran sebagai destinasi wisata alam laut terkenal di Jawa Barat, seperti disampaikan oleh Tresna dkk. (2019) dan Ibrahim (2019), kini menjadi pusat perhatian dari kalangan wisatawan, pemerintah daerah maupun pusat, serta dari berbagai kalangan profesional dan penguasaha, untuk selalu berbenah diri mengembangkan berbagai potensi dan peluangnya kearah yang lebih baik, seperti dicontohkan dari daerah lain oleh Subekti dkk. (2017).

Pemerintah daerah Kabupaten Pangandaran kini sedang giat melakukan beberapa pembenahan infrastruktur penunjang sebagai kota pariwisata (Supriatna, 2019). Namun demikian, peneliti melihat ada potensi lain yang jarang orang memikirkannya, yakni potensi Pandan (Pandanus tectorius). Peneliti melihat dari sisi alami (natural) dan kedaerahan (identitas kelokalan) yang tidak kalah pentingnya bagi pengembangan destinasi wisata daerah berwawasan global.

Penelitian industri kreatif penunjang pariwisata pada umumnya dan penelitian berbasis eco-wisata berbasis kawasan yang mengangkat potensi lingkungan alam setempat, memang sudah lama menjadi perhatian pengebang destinasi wisata, dan telah banyak dilakukan orang-orang sebelumnya, seperti dicontohkan oleh Mistiani 
dkk. (2018), Huang (2013), Yuan dkk. (2017), (Siswanto dkk. 2015), Sari (2008), Schianetz dkk. (2008), Holleran, (2008), dan Hwang dkk. (2005). Namun demikian, isu dan topik penelitian ini penting dan menarik untuk diangkat kembali karena daerah Kabupaten Pangandaran memiliki potensi tanaman pandan yang tumbuh luas di wilayah pesisir, seperti halnya potensi pandan di Orissa India (Panda dkk. 2009), di Tahiti (Stone, 1988), di Fiji (Ash, 1987), dan di Malaysia (Azahana dkk. 2015).

Berdasarkan pendataan riset awal dari 2017, kawasan pandan di Pangandaran ini teridentifikasi sekitar 44, 85 Ha tanaman pandan (pandanus tectorius) dan sebagain besar dari lahan tersebut kondisinya rusak, tidak dimanfatkan oleh masyarakat setempat dan juga tidak dikelola dengan baik oleh pemerintah setempat.

Topik eko-desain dan eko-wisata dengan objek kawasan pandan di Pangandaran ini belum pernah diteliti sebelumnya. Isu menarik lainnya yang mendorong kegiatan penelitian ini adalah banyaknya sampah dari berbagai kemasan produk serta kantong plastik pembungkus hasil belanjaan kebutuhan rumah tangga atau aktivitas pariwisata. Daun pandan ini dapat digunakan sebagai anyaman bahan produk ramah lingkungan untuk meminimalkan penggunaan kantong plastik yang berlebih. Dari salah satu isu ini didapatkan manfaat yang sangat signifikan khususnya untuk mengurangi sampah plastik yang belum dapat ditangani dengan baik. Dengan kata lain, potensi ini sangat mendukung terhadap pelestarian alam dan lingkungan sosial budaya masyarakat di wilayah pesisir Kabupaten Pangandaran untuk mengurangi limbah plastik dengan menggunakan produk-produk ramah lingkungan (seperti hasil riset ini dapat dilihat pada gambar $6-13$ ).

Isu lain selanjutnya, dalam konteks pasokan kebutuhan produksi skala menengah dan besar seperti yang ada di Karanganyar, Gompong, Kebumen, dan Rajapolah, Pandan ini dapat dibudidayakan untuk dimanfaatkan sebagai material bahan produk kerajinan maupun industri. Dengan demikian, penataan kawasan dan tata kelola sistem panen berkala kawasan Pandan tersebut dapat dilakukan dengan managemen yang lebih baik, seperti contoh dari konsep dan kegiatan sejenis yang telah dilakukan di negara lain (Wang, 2018), (Yuan et al., 2017).

Artikel ini dimaksudkan sebagai bentuk diseminasi dari practice-led research, salah satu bagian dari riset terapan multi tahun yang memiliki target capaian luaran seperti model purwarupa, prototipe produk unggulan, HKI, dan publikasi ilmiah jurnal atau prosiding seminar baik nasional/internasional, maupun naskah kebijakan hasil konsorsium antara pihak akademik, mitra pemerintah, mitra industri, mitra pelaku bisnis/trader, serta komunitas-komunitas terkait. Namun, dalam artikel ini hanya disampaikan sebagian kecil dari fokus kegiatan riset ini.

\section{METODE}

Berdasarkan beberapa pengalaman aplikasi sistem Tripel Helix dan Penta 
Helix dari peneliti lain sebelumnya, seperti Hermann,dkk. (2011), Kuznetsova,dkk. (2016), Hardianto,dkk. (2017), Halibas,dkk. (2017), Widowati,dkk. (2019), Putra, (2019), Aribowo,dkk. (2019) peneliti-peneliti ini menunjukan metode aplikasi sistem tersebut sangatlah tepat dan menunjukkan hasil sinergisitas kinerja yang baik. Namun, berbeda dengan objek penelitian ini yang mengangkat potensi alam kawasan Pandan berduri (Pandanus tectorius) sebagai objek penelitian yang berada di wilayah Kabupaten Pangandaran sebagai daerah wisata, maka objek ini dapat dijadikan produk-produk kriya pendukung pariwisata dan sekaligus dapat dijadikan kawasan destinasi baru (ekowisata) berbasis kawasan.

Berdasarkan permasalahanlahan pandan banyak yang rusak dan kurangnya kepedulian pemerintah setempat dalam penanganannya, maka penelitian ini lebih mengarah pada aspek tata kelola ekonomi-kreatif (seni kriya dan desain) yang mendukung pariwisata berbasis kawasan, sehingga diperlukan keterlibatan langsung tim peneliti dan mitra di lapangan, maka metode penelitian ini menggunakan metode Participation Action Research (PAR) dengan sistem pendekatan Hexa Helix yaitu Academic, Business, Government, Media Massa, Community, and Tourists (ABGMCT) (Putra 2018). Hexa Helix adalah pengembangan dari Penta Helix dengan penambahan wisatawan (tourist). Wisatawan penting didengar suaranya karena kepada merekalah destinasi wisata dan produk kerajinan berupa suvenir ditujukan (Putra 2018). Metode PAR ini menuntut keterlibatan langsung peneliti

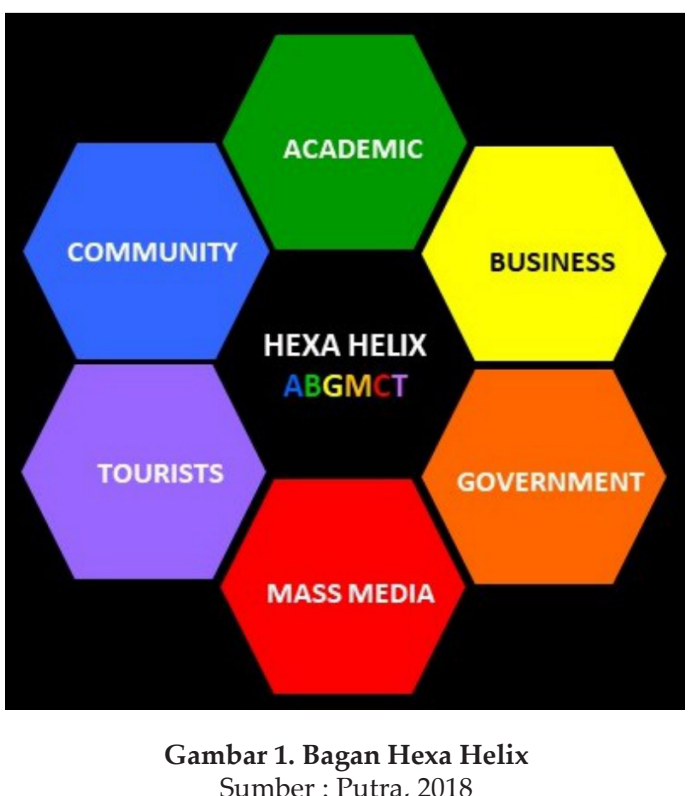

karena karkateristik objek penelitian terapan di lapangan yang berbentuk kawasan tanaman pandan (Pandanus tectorius). Pandan ini memiliki potensi aplikasi berbagai jenis produk yang memerlukan keterlibatan aktif langsung dari berbagai unsur terkait seperti DISPARBUD; IKM, UKM dan UMKM; PHRI, KWT, BUMDES, KPD, dan Karangtaruna.

Dari sistem penta helix disampaikan peneliti lain sebelumnya, penulis melakukan penambahan satu unsur helik yaitu Tourists seperti pada bagan nomor 1 .

Baik secara langsung maupun tidak langsung, tourists dapat diposisikan sebagai buyer dari produk-produk aplikasi Pandan. Selain itu, unsur lain seperti Business dan Government dapat berperan sebagai bapak angkat atau mitra kelompok para perajin pandan. Dari karakteristik objek dan situasi yang ada dalam sampel penelitian ini, perlu pertimbangan adanya jejaring dan interaksi yang membangun satu bangunan tata kelola lahan penyedia bahan baku, sistem produksi, marketing, dan distribusi yang kokoh sehingga dapat tumbuh dan berkembang 
secara berkesinambungan. Adapun pembahasan khusus yang lebih fokus dan spesifik terkait dengan luaran hasil practice-led research terapan ini, maka diperlukan metode turunan yaitu melalui proses kreatif design thinking : empathize, define, ideate, prototype, dan test (Christian Mueller-Roterberg, 2018 dan Hendriyana, 2018, hlm. 22-23).

a)Emphatize, tahap kegiatan awal untuk mendapatkan pemahaman empatik, khususnya dari permasalahan di kawasan pantai hubungannya dengan produk seni kriya serta objek wisata yang ada di Pangandaran. Mengidentifikasi keberadaan kawasan Pandan yang begitu banyak dan luas korelasinya dengan manfaat bagi lingkungan sekitarnya, khususnya dengan industri kreatif Kriya dan Pariwisata. Pada tahap ini, peneliti mencari mitra yang memiliki pandangan dan atau kegiatan yang dapat bersinergi dengan objek yang memiliki permasalahan serta peluang tinggi terhadap nilai tambah, kemudian menganalis dari para objek pelaku yang ada, pengguna, serta unsur pendukung yang berkaitan dengan pandan.

Tahap kegiatan ini dimaksudkan untuk mendapatkan dasar-dasar permasalahan yang dapat dijadikan inti kegiatan tahan selanjutnya. Untuk mendapatkan dasardasar permasalahan tersebut dapat dilakukan melalui proses empati, observasi, wawancara, studi literatur, dan tipologi terhadap objekobjek sejenis yang ada sebelumnya.

b) Define, tahap proses mengidentifikasi permasalahan lingkungan, khususnya terkait dengan potensi sumber daya alam Pandan dan sumber daya perajin yang terkait dengan industrik kreatif seni kriya, dan kepariwisataan di Pangandaran. Pada tahap ini peneliti mempertajam fokus permasalahan melalui proses analisis mendalam, programming, dan problem seeking dengan membuat :

1. Analisis kebutuhan perajin dan pengguna, solusi dan inovasi yang akan dikerjakan;

2. Design framework, merangkum dan merumuskan kesimpulan hasil analisis awal;

3. Problem statement dan konsep umum, sebagai rumusan pekerjaan untuk menyelesaikan permasalahan desain, khususnya yang berorientasi terhadap utility, significance, aesthetic, user, solution dan innovation.

c) Ideate, peneliti penciptaan merumuskan ide dan melakukan brainstorming dengan mind mapping yang detail, reliable, dan jelas sehingga menghasilkan :

1. Konsep desain yang dapat mendasari semua implementasi desain.

2. Pemberkasan transformasi desain yaitu dari image abstrak ke image kongkrit (transformasi visual, implementasi bentuk) dengan beberapa kemungkinan pekerjaan, seperti dengan menggambar sketsa style life atau dengan proses digital hingga menghasilkan beberapa desain alternatif.

d) Prototype, peneliti penciptaan mengerjakan proses studi spasial implementasi 
model 3D (pembuatan modeling) dan gambar kerja sehingga menghasilkan keputusan desain dan presentasi desain final yang dapat dipahami semua pihak terkait.

e)Test, 1) peneliti mempresentasikan tahapan ide hingga prototype yang telah dilakukan untuk mendapatkan feedback dari orang lain, apresiator, konsultan, dan klien atau mitra. Pada tahap ini diharapkan dapat meredefinisikan secara tuntas (finalisasi desain) dari temuan perbaikan/revisi sesuai fokus pada persoalan yang berhubungan dengan utility, significance, aesthetic, user, solution dan innovation. 2) uji kelayakan material bahan Pandan dan teknik pengerjaan maupun teknik pengujian secara terukur, rasional dan ilmiah.

\section{HASIL DAN PEMBAHASAN}

\section{Deskripsi Objek Pandanus}

Pandanus adalah salah satu nama kelompok (genus - marga) tumbuhan dari keluarga Pandanaceae. Genus ini terdiri atas berbagai jenis Pandan yang hidup tersebar di daerah-daerah terbuka di dataran rendah pada ketinggian 20-600 mdpl di hampir di seluruh daerah Asia hingga ujung timur Asia bahkan sampai kepulauan Pasifik [(Panda et al., 2009), (Stone et al., 1988) (Ash et al, 1987), (Azahana et al., 2015)]. Ciri utama Pandan adalah berukuran tinggi batang mencapai 4-14 $\mathrm{m}$ dan memiliki daun berwarna hijau dengan panjang 90-150 cm dan lebarnya mencapai 4-8 cm. Pandanus menghasilkan daun 10-300 lembar per batang per tahun.

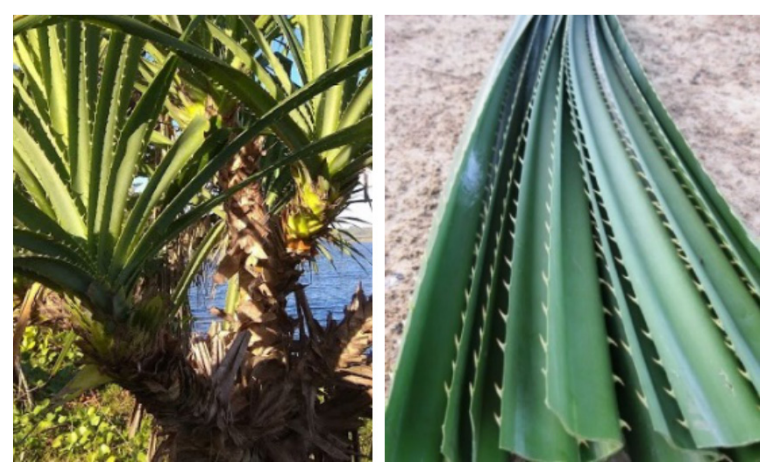

Gambar 2. Pandan berduri (Pandanus Tectorius Parkinson, Screw pine)

Sumber Foto : Hendriyana, 2019

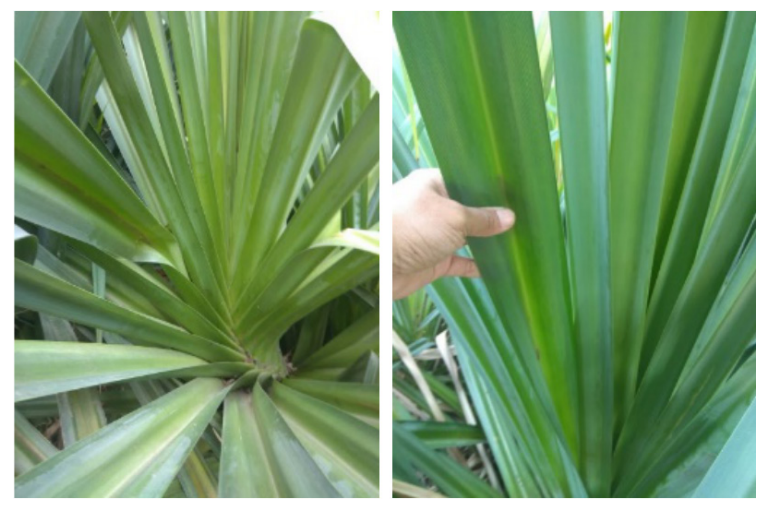

Gambar 3. Pandan tidak berduri (Pandanus Utilis, Screw pine) Sumber Foto : Hendriyana, 2019

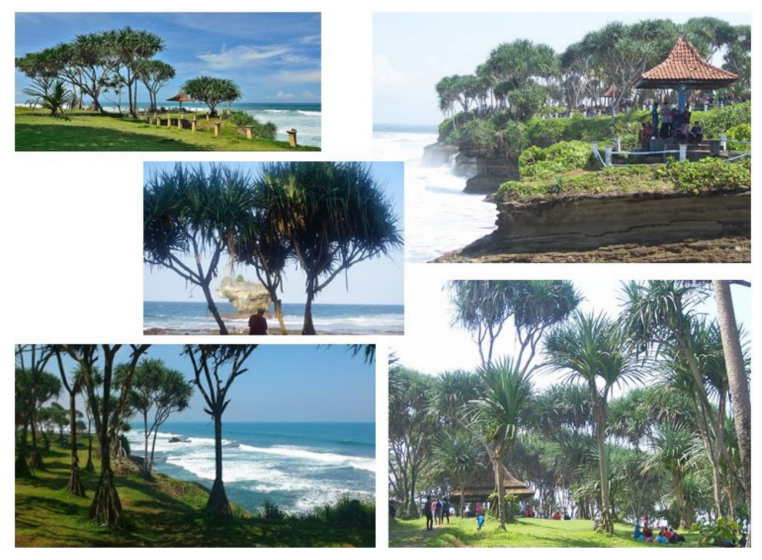

Gambar 4. Pandan yang difungsikan sebagai taman wisata di Batuhiu dan Mandasari, Pangandaran

Populasi Pandanus tectorius (Pandanaceae) ada di lokasi rawa pesisir dan gambut di Viti Levu, Fiji. Laju produksi daun (10-90 cm tahun-1), pertumbuhan batang dan cabang (2-80 cm - tahun-1) ditentukan dan digunakan melalui pengamatan jumlah dan jarak bekas luka daun dan bekas tangkai bunga untuk memperkirakan umur tanaman. Fase berikutnya 4,5 sampai dengan 9 tahun diikuti 


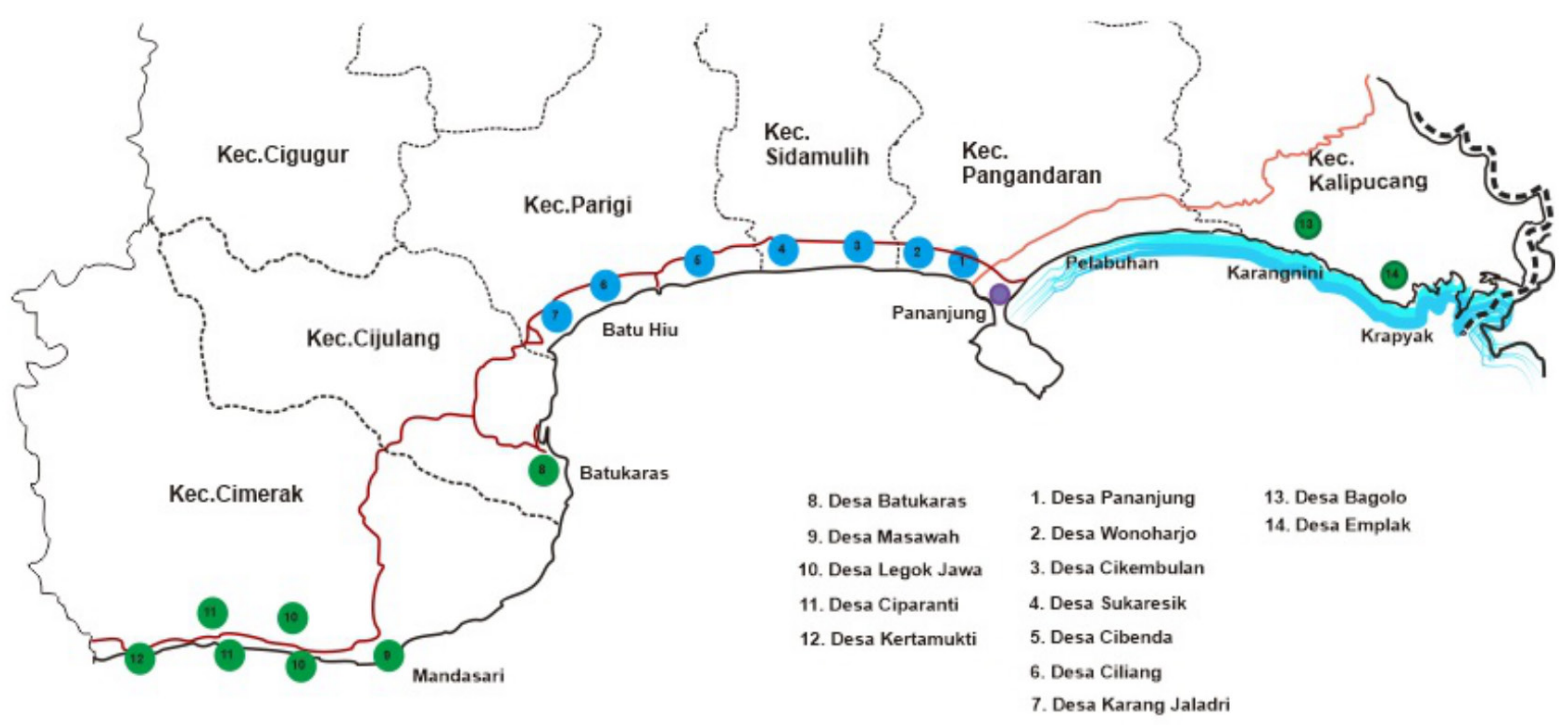

Gambar 5. Peta kawasan Pandan di wilayah Pesisir

Kabupaten Pangandaran

Sumber : Hedriyana, dkk., 2019

oleh pertumbuhan batang tegak selama 5-12

tahun, dan fase selanjutnya yaitu fase berbunga yang berlangsung Pandan berumur 40 tahun atau lebih. Tanaman jantan membentuk sekitar 30 cabang dan bunga setiap tahun, sedangkan tanaman betina membentuk sekitar 16 cabang dan bunga dua tahun sekali. Setiap buah membentuk dompolan buah pandan yang berisi sekitar 76 sampai 100 buah dan setiap satu biji buah mengandung hingga delapan embrio (biji kecil di dalam biji satu buah), meskipun terkadang banyak yang diparasit oleh larva serangga (Ash et al., 1987).

Daun Pandanus banyak digunakan untuk anyaman tikar, topi, payung, karung, tas, dan produk kriya lainnya [(Dahyanti, dkk., 2019), (Desnica,dkk., 2019), (Diniaty,dkk., 2014), (Wiwoho, 2013)] bahkan daun pandan kering dipilin menjadi tali (https://kumparan. com), (https://news.detik.com). Pada Suku Bali Aga, pandan digunakan pada acara ritual keagamaan upacara perang pandan.
Pada ritual keagamaan lainnya, pandan yang dibuat tikar melengkapi upacara daur hidup pembungkus mayit. Serat pandan digunakan untuk pembuatan penguat komposit beton semen (Hadi \& Gunawan, 2019); untuk penguat komposit kertas pengganti papan kayu (Jaffur \& Jeetah, 2019), (Bachtiar, Sulistyowati, \& Catur, 2015); dan untuk penguat kompostit genteng beton (Harahap et al., 2017). Pengolahan daun pandan pada umumnya dengan cara memotong daun pandan lalu direbus, dicuci dengan air bersih, kemudian dikeringkan di bawah terik matahari.

Dari hasil tinjauan empiris di lapangan maupun tinjauan sumber pustaka seperti disebutkan di atas, bahwa dalam perspektif industri kreatif seni kriya dan desain, daun pandan memiliki potensi yang sangat baik, yakni sangat memungkinkan untuk dijadikan bahan pendukung dengan berbagai jenis produk. 
Pangandaran, memiliki lahan pantai yang membentang sepanjang $91 \mathrm{~km}$, terdiri atas 21 destinasi wisata pantai dan memiliki lahan pasir seluas 283,55 ha (Sumber RPJMD 2016-2021). Berdasarkan survei di lapangan, lahan pasir di wilayah barat Kabupaten Pangandaran ditumbuhi pohon Pandan Berduri sepanjang kurang lebih 41,85 km. Tanaman Pandan tersebut tumbuh subur dan liar disepanjang wilayah tersebut. Sumber daya alam ini, dalam konteks pemberdayaannya berorientasi pada perancangan produkproduk unggulan Kabupaten Pangandaran. Dengan mengangkat satu objek kawasan Pandan sebagai komoditas produk kreatif Seni Kriya berbasis kawasan eko wisata, bila hal ini ditangani dengan fokus dan serius maka akan menjadi produk unggulan Kabupaten Pangandaran, seperti contoh pada program One Village, One Product (OVOP) yang telah dilakukan di Jepang dan China (Smith, 2019).

\section{Konsep Pemetaan Kawasan Pandan untuk} Mendukung Eko-Desain dan Eko-Wisata

\section{Berbasis Kawasan}

Berdasarkan pertimbangan potensi kawasan tanaman Pandan, lokasi, tempat, akses jalan dan lingkungan masyarakat desa yang berada di pinggiran daerah wisata Pangandaran, potensi ini dapat dibagi lima komoditas:

\section{Komoditas konservasi}

Pandan dapat dijadikan tanaman penahan angin laut yang mengarah pada pemukiman masyarakat serta dapat menahan abrasi pasir pantai (Dhiauddin dkk., 2019).
2.Komoditas Tumpangsari tanaman (turiman) dan tumpangsari penyu (turinyu).

(1). Tumpang sari penyu (turinyu) ini terinspirasi dari (Tisdell \& Wilson, 2002), (De Vasconcellos Pegas \& Stronza, 2010).

(2). Tumpang saritanaman(turiman) Pandan yang dirawat dengan baik sehingga tumbuh tinggi dan rindang di kawasan pantai, dapat dijadikan lahan tumpang sari tanaman melon/semangka; serta tempat bersarang penyu bertelur.

3.Komoditas edukasi dan pariwisata yang terinspirasi dari Tortuguero, Costa Rica (Jacobson \& Robles, 1992).

Penanaman beraneka jenis Pandan (seperti pandan laut/berduri, pandan wong/ gajah, cangkuang, mengkuang, Utilis, Pandan Bali, dll.) dapat dijadikan:

- lahan edukasi bagi para pelajar.

- tempat parkir, tempat (duduk santai) bagi wisatawan.

\section{Komoditas produk / industri}

Pandan dapat dimanfaatkan sebagai bahan produk anyaman (produk Craft and Eco design) untuk kebutuhan rumah tangga, souvenir/cinderamata serta untuk bahanbahan produk composite. Serat Pandan dapat dijadikan bahan baku olahan produkproduk composite building material seperti: Asbes, Glass-fiber Reinforced Cement (GRC) dan atau Glass Fiber Reinforced Concrete (GFRC) dengan beberapa varian seperti GRC panel, GRC cladding, GRC jali, GRC reinforce. Terkait dengan konsep ekodesain serat penguat produk-produk komposit ini 
dapat digantikan dengan serat Pandan yang ramah lingkungan [(Vigneshwaran et al., 2014) dan (Jaffur et al., 2019)], dan memiliki kekuatan yang sudah teruji [(Riyanto, 2019) dan (Firman,2015)]. Dengan demikian serat Pandan mampu menggantikan fiber glass import yang memang tidak ramah lingkungan (tidak membusuk terkubur tanah, dan juga tidak musnah dibakar) (Gambar : 16).

5.Komoditas sosio-kultural, yaitu melalui pemberdayaan dan pengembangan keterampilan masyarakat perajin daerah yang kemudian menjadi aktivitas mata pencaharian utama maupun tambahan yang dapat menghasilkan barang atau produk.

Dari kegiatan ini, masyarakat setempat dapat berhubungan langsung dengan pengelolaan material bahan pandan, sehingga memiliki pengetahuan dan ketrampilan tentang arts, craft, and design yang berbasis produk ramah lingkungan, berkarakter identitas lokal, seperti halnya produk kerajinan Payung Geulis Tasikmalaya (Sofyan, 2018).

\section{Siklus hidup produk Eco-design Pandan}

Pengelolaan produk dari tanaman Pandan terdiri atas:

\section{Cara memperoleh bahan baku}

Cara memperoleh bahan baku daun/ serat pandan yang memenuhi kapasitas sesuai kebutuhan produksi secara berkesinambungan, dapat dilakukan dengan pengelolaan dari lahan bebas/tanaman pandan liar yang ada di sepanjang harim laut (lahan hutan pantai) Kabupaten Pangandaran menjadi lahan budi daya pandan (pandanus tectorius). Pengembangan lahan produktif harim laut menjadi perkebunan pandan yang terkelola dengan baik ini terinspirasi dari pengetahuan, teori, konsep kegiatan yang telah dilakukan oleh beberapa peneliti lain sebelumnya, seperti (Milman, 2007) (Chudobiecki \& Wanat, 2015), (Tyl, Lizarralde, \& Allais, 2015) (Donnelly, Beckett-Furnell, Traeger, Okrasinski, \& Holman, 2006).

2. Metode proses pengolahan daun/serat pandan menjadi produk seni kriya dan produk lainnya.

Pada proses ini ditekankan untuk tidak menghasilkan limbah yang merusak lingkungan sekitarnya; dan diupayakan menggunakan energi/tenaga yang ramah lingkungan, tidak menimbulkan polusi udara, polusi suara, polusi air bersih ke lingkungan masyarakat sekitarnya. Salah satu metode alat yang digunakan dengan proses produksi dengan Alat Tenun Bukan Mesin (ATBM). Proses pemintalan serat pandan dengan menggunakan alat mekanik sederhana.

3. Penggunaan produk-produk yang terbuat dari bahan daun/serat Pandan

Produk yang terbuat dari bahan serat dan atau daun pandan termasuk ke dalam beberapa kategori produk jangka pendek, jangka menengah dan jangka Panjang.

a)Produk masa pendek:

(1) Produk dapat digunakan, atau berfungsi secara efektif dalam kurun waktu kurang dari tiga bulan.

(2) Produk dapat digunakan, atau 
berfungsi secara efektif dalam kurun waktu kurang dari lima bulan.

b)Produk masa menengah:

(1) Produk dapat digunakan, atau berfungsi secara efektif dalam kurun waktu kurang dari satu tahun.

(2) Produk dapat terurai oleh tanah, atau membusuk dalam kurun waktu kurang dari lima tahun

c)Produk masa panjang, produk dapat digunakan, atau berfungsi secara efektif dalam kurun waktu lebih dari 10 tahun.

4. Pembuangan dari produk-produk yang terbuat dari bahan daun/serat Pandan dan pengaruhnya terhadap lingkungan [(Kuan dkk., 2017) (Jaffur et al., 2019)].

Hal seperti ini penting diperhatikan, mengingat perncemaran alam dan lingkungan sebagaina besar dipengaruhi oleh sikap dan prilaku hidup manusia modern, dengan berbagai produk multi material yang memiliki rentang masa guna sangat berfariasi dan di masa pasca guna ada yang mudah terurai dan ada yang tidak bisa terurai oleh tanah [(Markowicz, Król, \& Szymanska-Pulikowska, 2019), (Markowicz \& Szymańska-Pulikowska, 2019), (Przybytek, Sienkiewicz, KucińskaLipka, \& Janik, 2018)]. Ada beberapa referensi terkait dengan keragaman jenis dan siklus produk dapat diklasifikasikan sebagai berikut:

a) Produk masa pendek, yakni produk yang dapat terurai oleh tanah atau membusuk dalam kurun waktu kurang dari tiga bulan.

Contoh produk: Pipiti kemasan kemasan produk kuliner, fiber serat pandan pengharum ruangan, aroma terapi. b) Produk masa menengah yakni produk yang dapat terurai oleh tanah atau membusuk dalam kurun waktu kurang dari satu tahun

Contoh produk: anyaman daun pandan seperti tikar, tas, sendal, topi dan tempat tisu, alas kaki interior mobil.

c) Produk masa menengah, yakni produk yang dapat terurai oleh tanah atau membusuk dalam kurun waktu kurang dari lima tahun

Contoh produk: kain, tenun berbahan serat alam.

d) Produk masa panjang, yakni produk yang dapat terurai oleh tanah, atau membusuk dalam kurun waktu lebih dari 10 tahun.

Contoh produk: composite building material seperti asbes, GRC dengan beberapa varian: GRC Panel, GRC Cladding, GRC Jali, GRC Rainforced; GFRC. Untuk mengurangi limbah yang dapat mencemari lingkungan, maka hal ini sangat meungkinkan glass fiber diganti dengan pandanus fiber atau tectorius fiber (seperti Gambar : 13 dan 14).

\section{Tahapan Proses Pengerjaan}

Berdasar pada alur metode perwujudan karya di atas, maka dapat dideskripsikan tahapan proses practice-led research kriya pandan sebagai berikut:

1.Emphatize, adalah untuk mendapatkan pemahaman empatik dari permasalahan yang akan dipecahkan. Pada tahap ini peneliti merekam dan mengangkat permasalahan dan potensi yang ada dengan mencari berbagai peluang kebermanfaatan material bahan Pandan, lalu mempelajari user, serta mencari berbagai alternatif solusi pemecahan masalah yang didapatkan melalui empati, observasi, 
wawancara, studi literatur, dan tipologi terhadap produk-produk sejenis yang ada sebelumnya dan atau tipologi karakteristik objek sejenis di daerah lain.

Pada tahap ini peneliti mendapat empati permasalahan dari :

a) banyaknya lahan pandan yang rusak karena kurangnya pemahaman masyarakat setempat akan pontesi daya guna tanaman pandan tersebut, sebagian besar masyarakat menganggap pandanus tectorius sebagai tumbuhan gulma-rumput besar berduri yang mengotori pantai, tidak berguna bahkan berbahaya bagi masyarakat karena duridurinya yang tajam;

b) berdasarkan survey di lapangan, Pangandaran memiliki lahan tumbuhan Pandan (Pandanus tectorius) sekitar 44,85 km dari $91 \mathrm{~km}$ panajang wilayah pesisir Kabupaten Pangandaran tidak banyak dimanfaatkan oleh masyarakat perajin setempat, melainkan diambil oleh masyarakat dari luar Kabupaten Pangandaran bahkan dari luar Jawa Barat, mereka mengambil daun pandan dengan sistem ijon kepada warga yang berdekatan dengan lahan pandan tersebut;

c) berdasarkan literatur sejarah, dari jaman nenek moyang, masyarakat menggunakan alas dari anyaman pandan di setiap rumah, hingga dipergunakan sebagai pembungkus mayat setelah kain kafan bagi umat muslim (Wilardjito, 2009, hlm. 38);

d) berdasarkan survey ke sentra kerajinan di beberapa daerah, seperti Rajapolah Tasikmalaya, Karanganyar, Gombong, Kebumen, Kulonprogo Yogyakarta didapatkan bahwa banyak produk kerajinan dan produk barang kebutuhan rumah tangga yang dibuat dari anyaman daun Pandan;

e) menganalisa material bahan anyaman pandan dari berbagai produk aplikasinya, memiliki keunikan dan konsep produk yang ramah lingkungan.

2.Define, adalah proses mengidentifikasi permasalahan yang lebih fokus dan detail. Pada tahap ini desainer/peneliti penciptaan menemukan dan atau mempertajam fokus permasalahan melalui proses analisis mendalam, programming, dan problem seeking dengan membuat :

a) Analisis kebutuhan user, solusi dan inovasi yang akan dikerjakan.

Pada tahap ini peneliti lebih fokus pada studi bahan, teknik, dan bentukbentuk produk yang dapat dibuat, dengan mempertimbangkan peluang pasar dari berbagai kalangan, baik kalangan masyarakat desa maupun kota, kalangan tua maupun muda, kalangan wanita maupun laki-laki, baik kalangan perajin maupun pengusaha seperti hotel dan restoran.

b) Design framework, sebagai rangkuman dan rumusan hasil analisis awal.

Pada tahap ini peneliti merancang produk aplikasi Pandan dengan beberapa desain alteranif hingga keputusan desain yang terpilih, melalui beberapa uji pasar dan uji estetik.

c)Problem statement dan konsep umum, sebagai rumusan pekerjaan untuk menyelesaikan permasalahan desain.

Pada tahap ini peneliti lebih memfokuskan, hal-hal terkait dengan tema, 
isu, permasalahan objek, permasalahan masyarakat pengelola (managemen produksi) maupun masyarakat pengguna (pasar).

3. Ideate, desainer/peneliti penciptaan merumuskan ide dengan melakukan brainstorming dengan menggunakan metode mind mapping sehingga menghasilkan :

a) Konsep desain yang dapat mendasari semua implementasi desain.

Untuk mendapatkan konsep yang baik sesuai keputusan desain point 3.b di atas, maka pada tahap ini perlu diuji melalui studi banding terhadap kualitas produk dan pasar di beberapa tempat di luar wilayah Pangandaran.

b) Perancangan gambar kerja yang baik.

Pada tahap ini peneliti melakukan pemberkasan transformasi desain dengan membuat mind mapping yang baik, dari image abstrak ke image kongkrit (implementasi bentuk) dengan beberapa kemungkinan pekerjaan yang dilakukan untuk mendukung perwujudan karya seperti dengan menggambar style life maupun dengan komputer untuk menghasilkan perancangan gambar kerja yang yang lebih jelas.

4.Prototype, pada tahan ini desainer/ peneliti mengerjakan proses studi spasial implementasi model 3D (pembuatan modeling) dan gambar kerja sehingga menghasilkan keputusan desain dan presentasi desain final. Pada tahap ini perlu juga dilakukan uji kelayakan produk dengan berbagai uji bentuk, kekuatan, kenyamanan, dan artistik atau daya tarik bagi konsumen.
5. Test,desainer/peneliti mempresentasikan tahapan ide hingga prototipe yang telah dilakukan untuk mendapatkan feedback dari orang lain, apresiator, konsultan, dan klien. Pada tahap ini diharapkan dapat mendefinisikan kembali fokus permasalahan yang ada masih ada pada produk dan penggunanya, sehingga dapat terukur tingkat keberhasilan dari solusi dan inovasi yang telah dilakukan. Dengan kata lain, pada tahap ini lebih pada tingkat pencapaian kualitas problematik produk, tepat guna, dan terpat sasaran, sehingga pada tahap selanjutnya dapat dibuat dalam jumlah banyak dengan tingkat kegagalan yang sangat minim.

\section{Prototipe Produk Unggulan Kriya Pandan}

Berikut disampaikan prototipe produk aplikasi hasil practice-led research ini, produkproduk tersebut dirumuskan berdasarkan pertimbangan potensi SDA serta SDM yang ada dan tersedia di lingkungan masyarakat setempat dan dihubungkan dengan kebutuhan yang menunjang kepariwisataan di Pangandaran. Dengan kata lain, difersivikasi produk ini didesain berdasarkan pertimbangkan skala prioritas dengan tema, fungsi, dan bentuk yang disesuikan dengan produk-produk ekodesain yang mendukung pariwisata di Kabupaten Pangandaran. Aplikasi tindakan penelitian ini berorientasi menumbuhkan star up bisnis dan diharapkan dengan keterlibatan pemerintah setempat dapat membentuk yang keberlanjutannya, seperti disampaikan contoh di daerah Sragen, Jawa Tengah (Setiawan, 2017). 


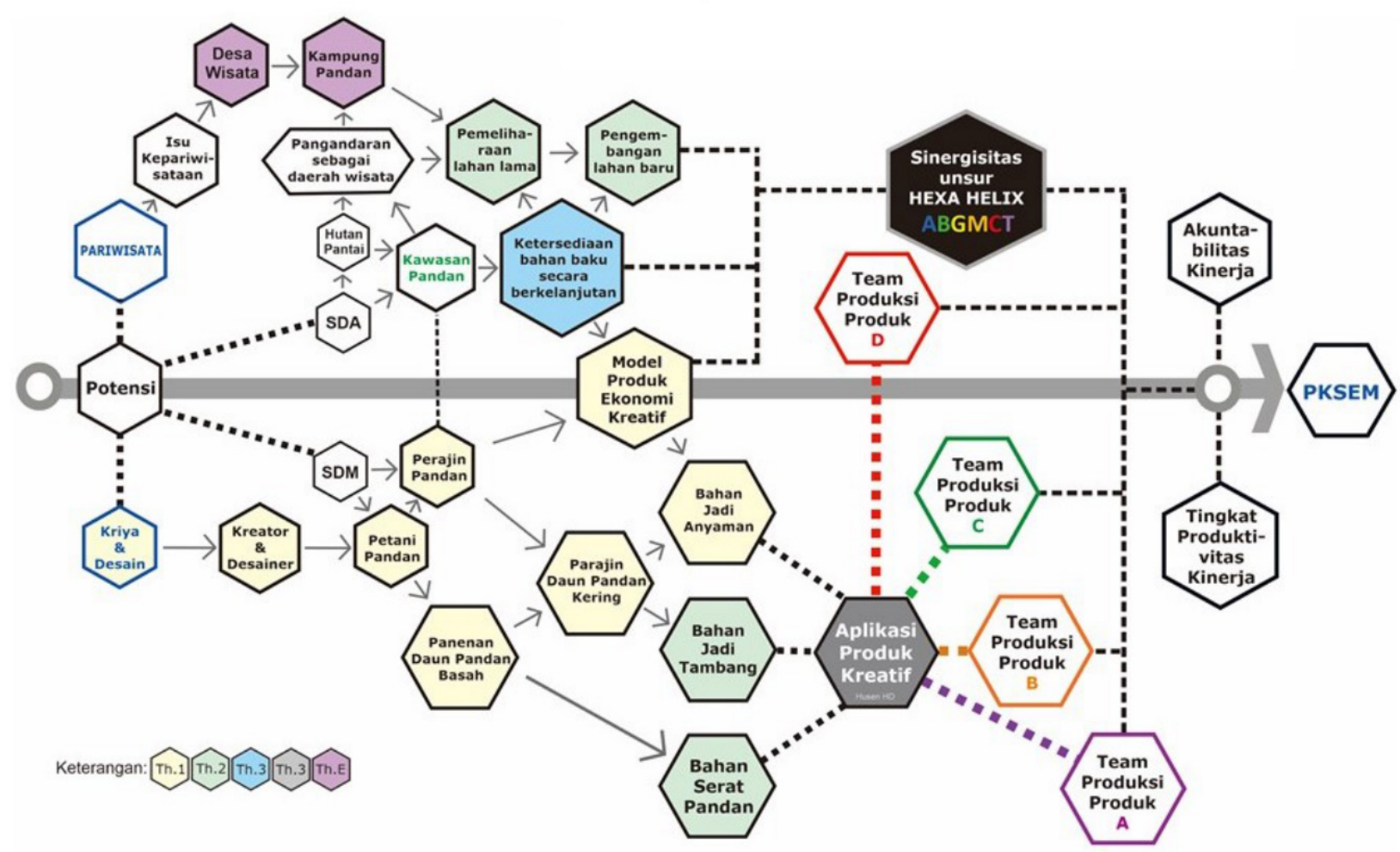

Gambar 6a . Bagan Model Desain Riset Terapan Industri Kreatif Kriya mendukung Pariwisata Keterangan: PKSEM (Peningkatan Kesejahteraan Sosial dan Ekonomi Masyarakat)

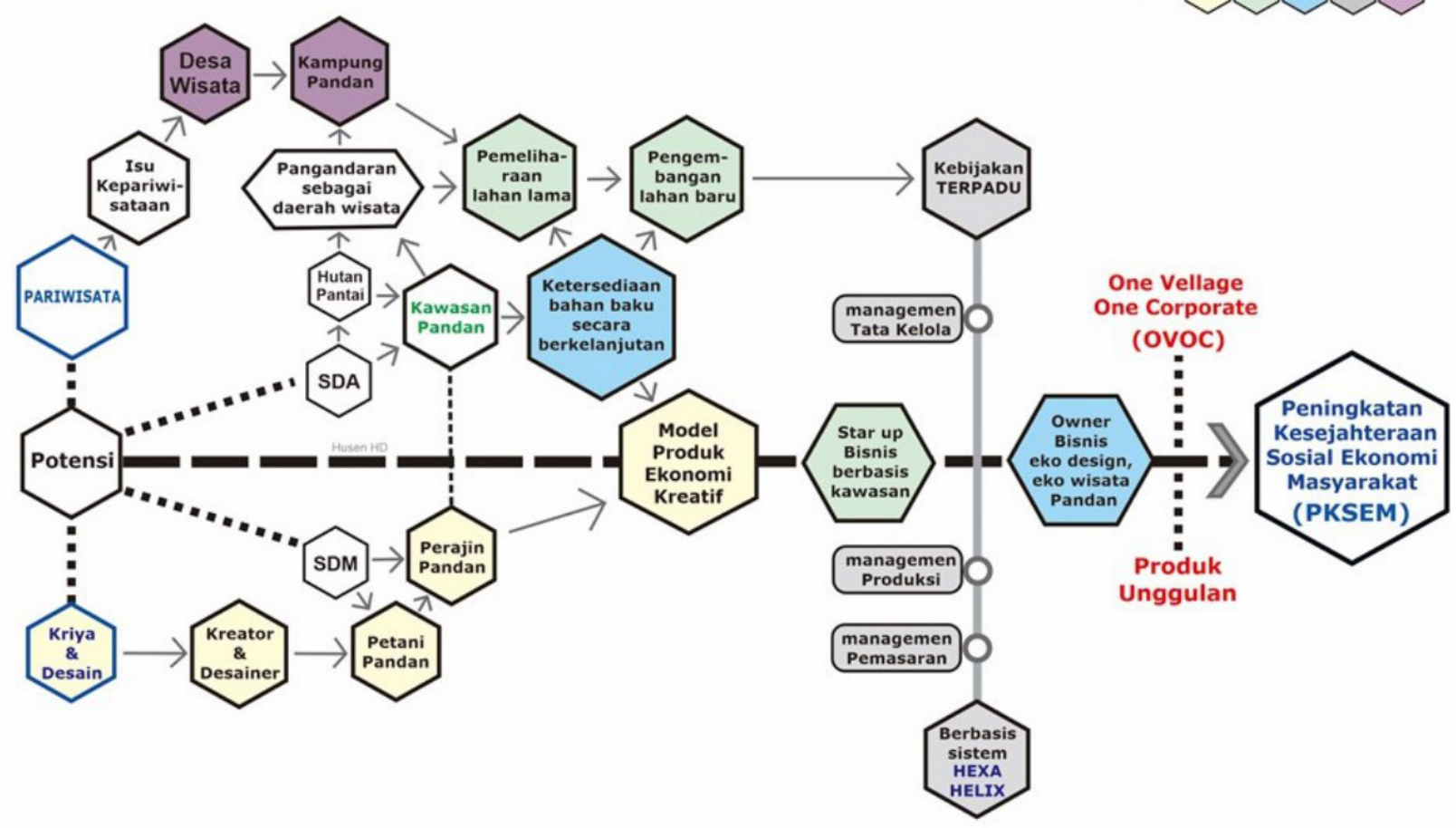

Gambar 6b. Star up bisnis Kriya Pandan, kebijakan terpadu - tata Kelola pandan 
Prototipe produk unggulan hasil Penelitian ini terdiri atas :

1. Shopping Bag Eco Friendly (SBef) (Gambar 7).

2. Piranti Makan Tematik Eco Friendly (PMTef), (Gambar 8).

3. Topi Pantau Wisatawan Eco Friendly (TPWef), (Gambar 9).

4. Totebag \& Goodibag Eco Friendly (TGef), (Gambar 10).

5. Gelang dan Tasbi Eco Friendly (GTef), (Gambar 11).

6. Aplikasi Produk - Tambang Pilin Daun Pandan (Gambar 12) yang terinspirasi dari pemanfatan serat daun nanas untuk produk furniture (Milliati \& Estiyono, 2019).

7. Aplikasi produk Pandanus Tectorius - Natural Fiber Reinforced Composite, (Gambar 13 dan 14) yang terinspirasi dari aplikasi hasil riset sejenis sebelumnya (Supriyatna \& Solihin, 2018), (Harahap \& Purba, 2017), (Vigneshwaran,dkk. 2014).

Sesuai dengan tujuan artikel ini, maka luaran hasil aplikasi produk sub dari practiceled research ini dapat dibatasi pada produk prototipe/purwarupa dan desain peta riset sebagai berikut:
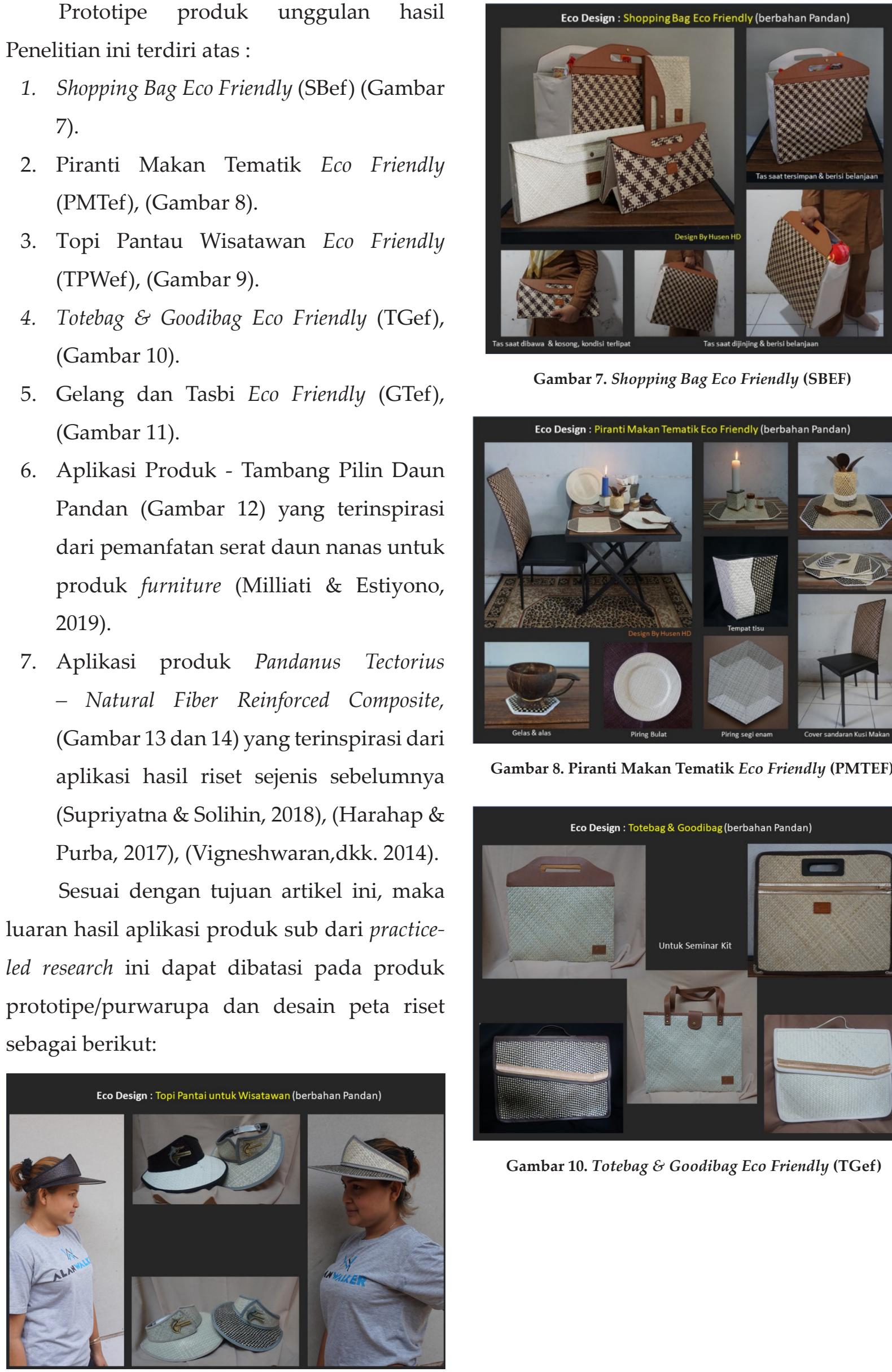

Gambar 7. Shopping Bag Eco Friendly (SBEF)

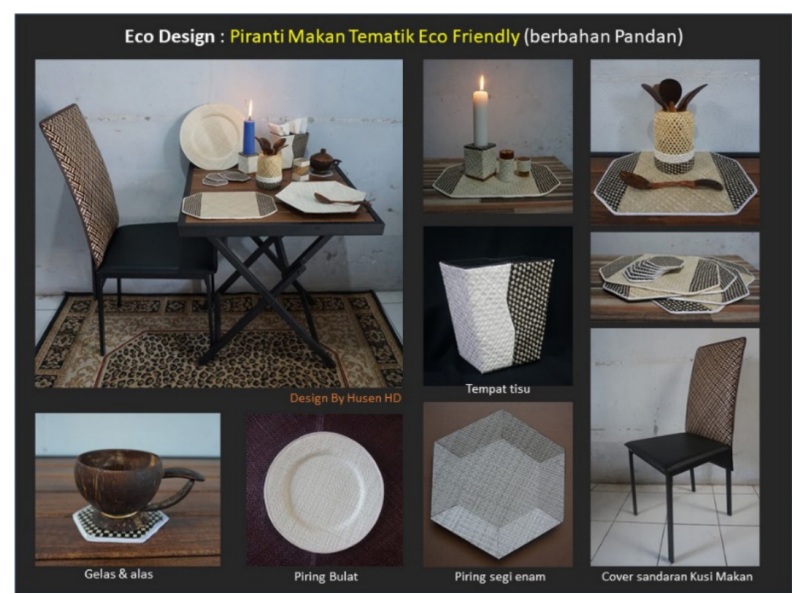

Gambar 8. Piranti Makan Tematik Eco Friendly (PMTEF)

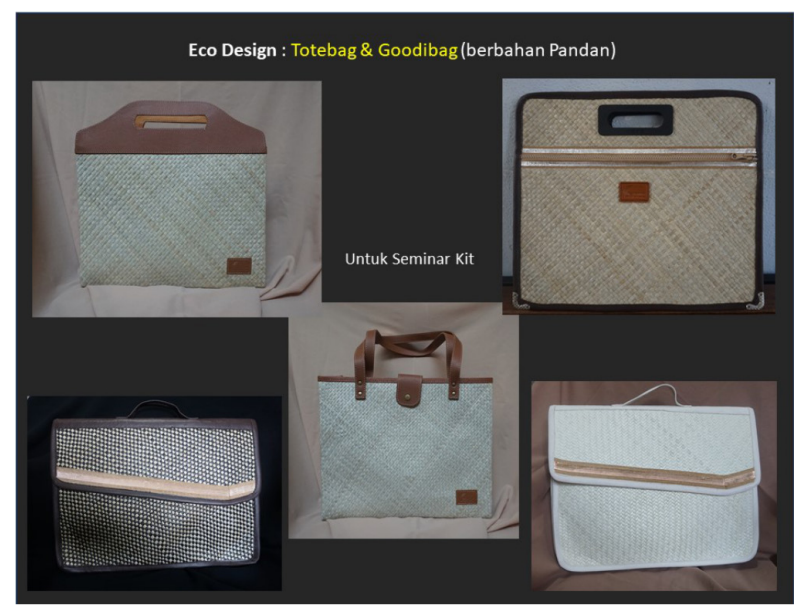

Gambar 10. Totebag \& Goodibag Eco Friendly (TGef) 


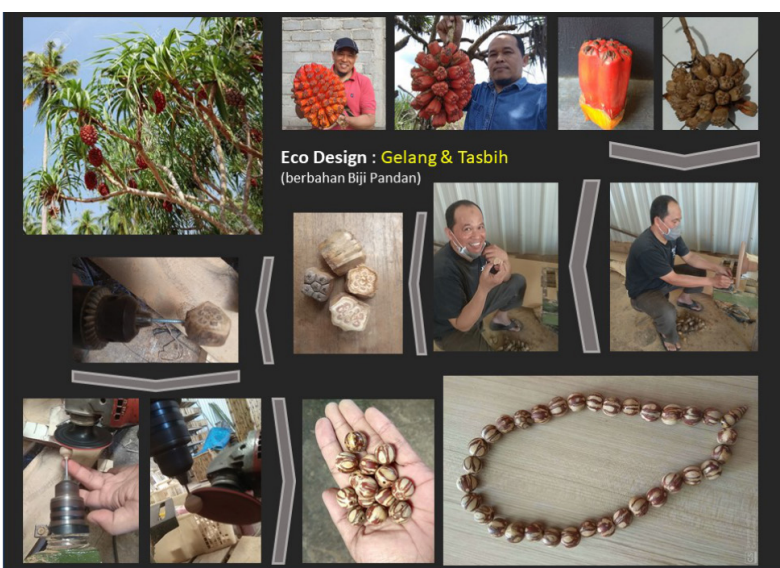

Gambar 11. Gelang dan Tasbi Eco Friendly (GTef)

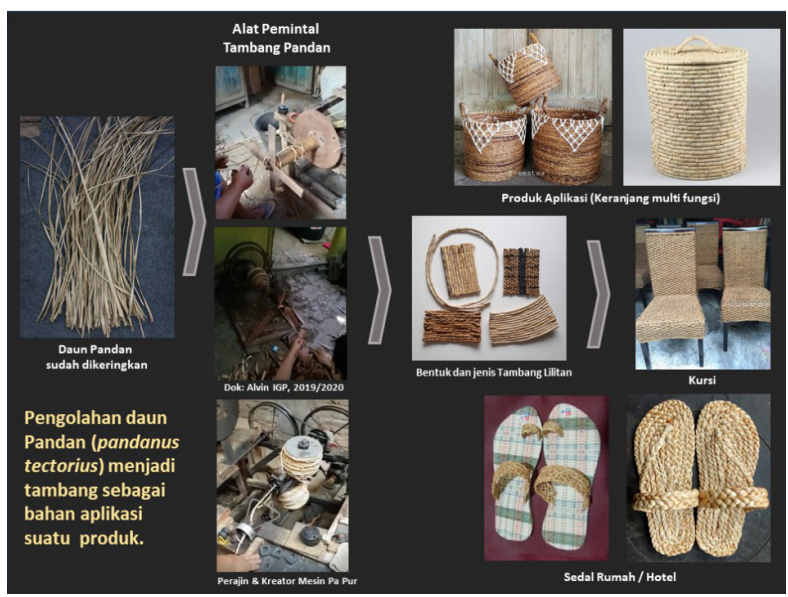

Gambar 12. Aplikasi Produk - Tambang Pilin dan Daun Pandan

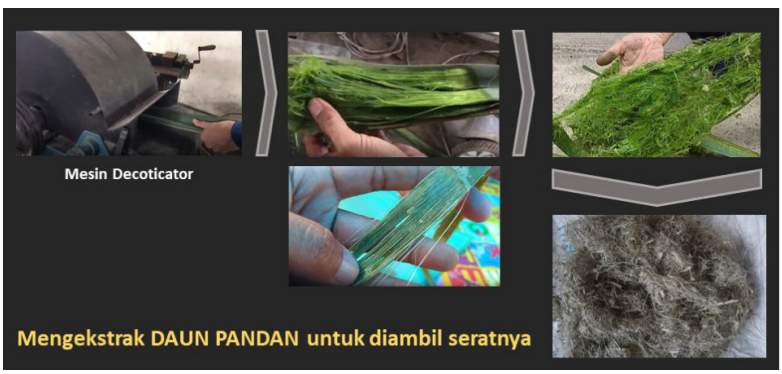

Gambar 13. Tekstur Serat Pandan

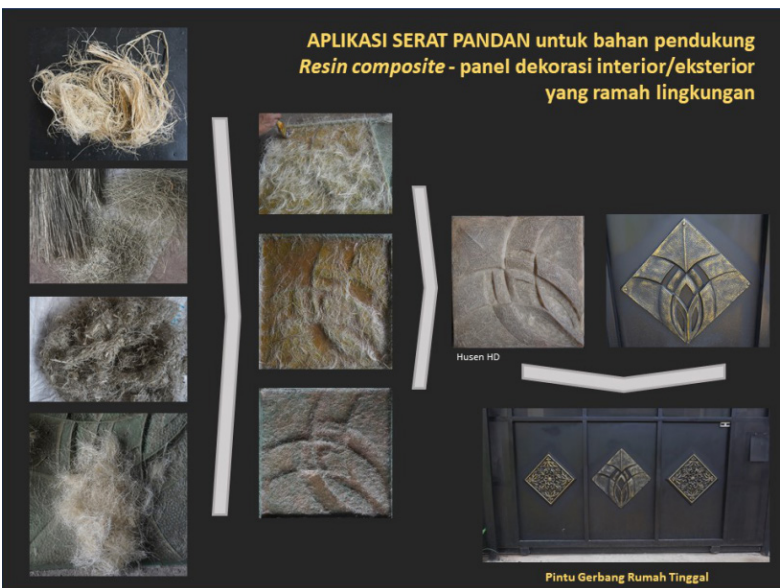

Gambar 14. Pandanus Tectorius - Natural Fiber Reinforced Composite

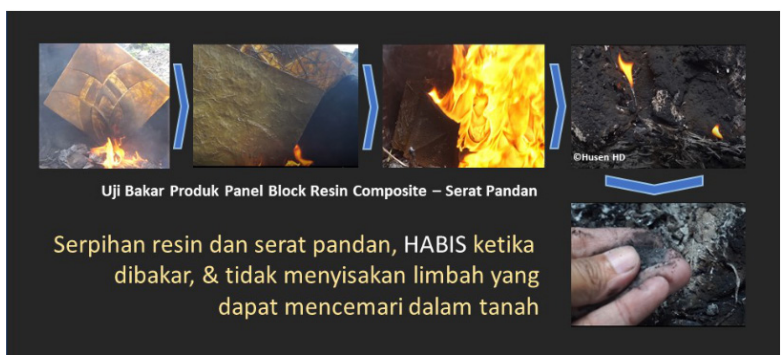

Gambar 15. Uji Bakar Produk Panel Block Resin Composite Tectorius fiber

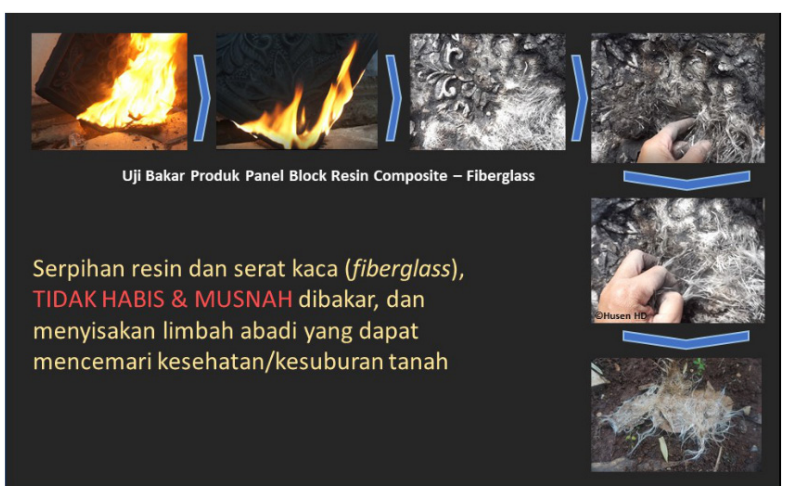

Gambar 16. Uji Bakar Produk Panel Block Resin Composite - Glass fiber

\section{PENUTUP}

Berfokus pada jenis Practice-led Research ini, maka kesimpulan dari penelitian ini adalah (1) model desain proses kreatif dengan beberapa unsur pengaruh atau unsur pertimbangan dalam penciptaan produk karya seni kriya mendukung pariwisata berbasis kawasan yang memperhatikan pada lingkungan dan keberlanjutannya. Model proses kreatif ini dapat digambarkan dalam bentuk bagan (Gambar 6). (2) Luaran kedua, adalah Star up bisnis melalui Komunitas Penggiat Pandan (KP2) dan Kelompok Petani dan Perajin Pandan (KP3) yang terdiri dari para pemuda Karangtaruna dan ibu-ibu Kelompok Wanita Tani (KWT).

Mencermati luaran penelitian disampaikan di atas, bahwasanya kekuatannya bukan hanya pada hilirisasinya, melainkan pada penguatan pengetahuan, 
Pentahelix Pariwisata di Jawa Timur

keterampilan, serta penyadaran sosial ecodesign dan atau internalisasi nilai-nilai sosialbudaya masyarakatnya. Artinya, luaran hasil penelitian fokus seni budaya, sosial humaniora itu tidak hanya pada satu bidang sasaran penguatan nilai ekonomi dan bisnis praktis. Otokritik ini memberikan rekomendasi risetriset selanjutnya yang berhubungan dengan nilai tambah ilmu pengetahuan, dampak sosial, ekonomi produk, dan identitas budaya bangsa, serta kebijakan publik tata kelola kawasan pandan di Kabupaten Pangandaran.

Terakhir, bisa ditegaskan bahwa penghargaan kepada panda (Pandanus tectorius) tidak saja sebagai bahan baku produk seni ekodesain, tetapi juga pada lanskap pandan sebagai ekowisata. Siklus dari pandan menjadi produk seni kerajinan, atau dari produk seni wisatawan bisa diberikan kesadaran atau pengalaman untuk menikmati ekowisata, yakni lanskap pandan hijau berduri yang memukau hati wisatawan setiap hari.

Terima kasih penulis sampaikan kepada Simlitabmas dan LPPM ISBI Bandung, bahwa artikel ini merupakan salah satu luaran publikasi ilmiah hasil penelitian terapan yang didanai oleh Ristekdikti/Ristekbrin 2019-2021.

\section{Daftar Pustaka}

Aribowo, H., Wirapraja, A.,\& Putra, Y.D. (2018). Implementasi Kolaborasi Model serta Meningkatkan Perekonomian Domestik. Jurnal Mebis (Managemen dan Bisnis).Vol.3 No.1, July 2018.p.3138. Doi: 10.33005/mebis.v3i1.21

Ash, J. (1987). Demography, Dispersal and Production of Pandanus Tectorius (Pandanaceae) in Fiji. Australian Journal of Botany. 35(3), pp. 313 - 330. Doi: 10.1071/BT9870313

Azahana, A., Wickneswari, R., Noraini, T., Nordahlia, A.S., Solihani, N.S., \& Nurnida, M.K. (2015). Notes on Pandanus atrocarpus Griff and Pandanus tectorius Parkinson in Peninsular Malaysia. In AIP Conference Proceedings.Vol 1678. Published Online: 25 September 2015. Doi: $10.1063 / 1.4931208$

Bachtiar, S., Sulistyowati, E.D., \& Catur, A.D. (2015). Analisis Sifat Penyerapan Air dan Indeks Nyala Api pada Papan Komposit yang di perkuat Serat Daun Pandan duri dan Limbah serbuk gergaji kayu Sengon dengan Resin Polyester. Dinamika Teknik Mesin. Volume 5 No. 2. Juli 2015.pp. 73-81. Doi: 10.29303/d. v5i2.32

Chudobiecki, J., \& Wanat, L. (2015). Industrial Symbiosis and Green Business Park in the Wood-based sector in Poland. In Wood Processing and Furniture Manufacturing Challenges on the World Market and Wood-Based Energy Goes Global - 8th International Scientific Conference, Proceeding of Scientific Papers. Hotel Astarea, Mlini / Dubrovnik, Croatia, October 7th 9th 2015.

Dahyanti, Gusti Hardiansyah, dan L.Sisilia. (2019). Pemanfatan Hasil Hutan Bukan Kayu (HHBK) Penghasil Kerajinan Tangan Anyaman oleh Masyarakat Desa Pangkal Buton Kecamatan Sukadana Kabupaten Kayoung Utara. Jurnal Hutan Lestari.Vol 7, No 4. pp. 1512 - 1523.

De Vasconcellos Pegas, F., \& Stronza, A. (2010). Ecotourism and Sea Turle Harvesting in a Fishing Village of Bahia, Brazil. In Journal Conservation and Society.Vol 
8. Issue 1.pp.15-25. Doi: 10.4103/09724923.62676

Desnica, P., Widiawati, D., \& Nugraha, A. (2019). Pengembangan Dekorasi Warna pada Anyaman Pandan Tasikmalaya. Dinamika Kerajinan dan Batik: Majalah Ilmiah. Vol. 36 No.1, Juni 2019, Hal. 7180. Doi: 10.22322/dkb.v36i1.5127.

Dhalyana, Dini; Adiwibowo, Soeryo. (2013). Pengaruh Taman Wisata Alam Pangandaran Terhadap Kondisi Sosial Ekonomi Masyarakat (Studi: Desa Pangandaran, Kecamatan Pangandaran, Kabupaten Ciamis, Provinsi Jawa Barat), SODALITY: Jurnal Sosiologi Pedesaan Vol 1, No 3 (2013) DOI: 10.22500/sodality.v1i3.9402 Dhiauddin, R., Gemilang, W.A., Ondora, K., Wisha, U.J., Rahmawan, G.A., \& Kusumah, G. (2019). Integrated Method of Smartline Approach and CVI (Coastal Vulnerability Index) in Assessing Pangandaran West Coast Vulnerability. Jurnal Segara. Vol.15, No.2. pp.109-117. Doi: 10.15578/segara. v15i2.7001

Diniaty, D., \& Agusrinal. (2014). Perancangan Strategi Pemasaran pada Produk Anyaman Pandan (Studi Kasus: Home Industry Saiyo Sakoto di Kenagarian Padang Leweh, Kecamatan Koto VII Kabupaten Sawahlunto Sijunjung). Jurnal Sains, Teknologi dan Industri. Volume 11. Nomer 2. Hal.175-184. Doi: 1693-2390.

Donnelly, K., Beckett-Furnel, Z., Traeger, S., Okrasinski, T., \& Holman, S. (2006). Eco-design Implemented Through a Product-based environmental management system. Journal of Cleaner Production. Volume 14. Issue 15-16. pp. 1357-1367. Doi: 10.1016/j. jclepro.2005.11.029.

Firman, S.H., Muris, \& Subaer. (2015). Studi Sifat Mekanik dan Morfologi Komposit Serat Daun Pandan Nanas-Epoxy Ditinjau dari Fraksi Massa dengan Orientasi Serat Acak. Jurnal Sains dan Pendidikan Fisika. Jilid 11, Nomer 2, Agustus 2015, hal.185-191.UNM Makasar.
Hadi, F.,\& Gunawan, A. (2019). Pengaruh Lama Pengeringan Beton Serat Pandan pundak duri (Pandanus Tectorius) terhadap Kuat Tarik Belah Beton. Inersia, INERSIA Jurnal Teknik Sipil. Vol.11, No.1 hal.1-6. Doi: 10.33369/ ijts.11.1.1-6.

Halibas, A. S., Sibayan, R.O., \& Maata, R.L.R. (2017) The Penta Helix Model of Innovation in Oman: An Hei Perspective. Interdisciplinary Journal of Information, Knowledge, and Management (IJIKM), Vol.12. pp.159174.

Harahap, M.H., \& Purba, E.Y. (2014). Pemanfatan Serat Daun Pandan Duri sebagai Campuran dalam Peningkatan Karakteristik Genteng Beton. Einstein Journal.Vol.2 No.1. Februari, pp.1-10. Doi: 10.24114/einstein.v2i1.5096

Hardianto, W.T., Sumartono, MR. Khairul Muluk, \& Wijaya, A.F. (2017). Tourism Investment Services in Batu City with Penta Helix Perspective. International Journal of Management and Administrative Science (IJMAS). Vol.5, No.5. pp.17-22.

Hendriyana, H. (2018). Metodologi Penelitian Penciptaan Karya: Seni Kriya dan Desain non Manufaktur. Bandung: Penerbit Sunan Ambu Press. Isbn: 978979-8967-77-1

(2019). RUPA DASAR (NIRMANA) Asas dan Prinsip Dasar Seni Visual (Philosophy and Theory of Fine and Decorative Arts). Yogyakarta : Penerbit Andi. ISBN: 978-623-01-02288.

Hendriyana, Husen, Wayan Darma Putra dan Yan Yan Sunarya. (2019). “Eco design : Eksplorasi dan Aplikasi Material Bahan Pandan Berduri untuk Mendukung Ekonomi Kreatif Kriya Seni dan Pariwisata di Pangandaran" Laporan penelitian Simlitabmas tahun I.

RUPA DASAR (NIRMANA) Asas dan Prinsip Dasar Seni Visual (Philosophy and Theory of Fine and Decorative Arts). Yogyakarta : Penerbit Andi. ISBN: 978623-01-0228-8.

Hermann, R.R., Riisgaard, H., \& Remmen, 
A. (2011). Triple Helix Interactions for Eco-innovation in the Developing World; Insights from the Panama Canal Watershed. 9th International Triple Helix Conference. July 11-14, Tusur University, Tomsk, Russia.

Hidayat, Marceilla. (2011). Strategi Perencanaan dan Pengembangan Objek Wisata (Studi Kasus Pantai Pangandaran Kabupaten Ciamis Jawa Barat), Tourism \& Hospitality Essentials (THE) Journal, Vol 1, No 1, Publisher : Universitas Pendidikan Indonesia, DOI: 10.17509/thej.v1i1.1879.

Holleran, J.N. (2008). Sustainability in Tourism Destinations: Exploring the Boundaries of Eco-efficiency and Green Communications. Journal of Hospitality and Leisure Marketing. Volume 17, Issue 3-4, pp. 373-394. Doi: 10.1080/10507050801985104

Huang, M.H. (2013). The Mechanics of Managing the Cultural and Creative Industry Park Cultural and Creative Industry Park National Taiwan University of Art. International Journal of Education Through Art. Vol. 9, N.3, October 2013, pp. 357-368. Doi : 10.1386/eta.9.3.357_1

Hwang, S.N., Lee, C., \& Chen, H.J. (2005). The Relationship among Tourists Involvement, Place Attachment and Interpretation Satisfaction in Taiwan's National Park. Tourism Management Journal. Volume 26, Issue 2, April 2005, pp. 143-156. Doi: 10.1016/j. tourman.2003.11.006.

Ibrahim Rashid. (2019). Toward a Tourism Destination Brand Equity of Coastal Tourism of Pangandaran Regency. Jurnal Perspektif Pembiayaan dan Pembangunan Daerah (Journal of Perspectives on Financing and Regional Development). Vol. 7. No 2. September-October. pp.183-194. Vol. Doi: $10.22437 / p p d . v 7 i 2.7483$.

Jacobson, S.K., \& Robles, R. (1992). Ecotourism, Sustainable Development, and Conservation Education: Development of a Tour Guide Training Program in Tortuguero, Costa Rica. Environmental
Management. Volume 16. Issue 6. Nov/Dec. pp.701-713. Doi: 10.1007/ BF02645660.

Jaffur, N.,\& Jeetah, P. (2019). Production of Low Cost Paper from Pandanus Utilis Fibres as a Substitution to wood. Sustainable Environment Research. Vol.29. Issue 20. pp.1-10 Doi: 10.1186/ s42834-019-0023-6

Kuan, H. T. N., Lee, M. C., Khan, A. A., \& Sawawi, M. (2017). The Low Velocity Impact Properties of Pandanus Fiber Composites. Materials Science Forum. Doi.org/10.4028/www.scientific.net/ msf.895.56

Kuznetsova, E., Zio, E., \& Farel, R. (2016). A Methodological Framework for Eco-Industrial Park Design and Optimization. Journal of Cleaner Production. Volume 126. 10 July 2016. Pp. 308-324. Doi: 10.1016/j. jclepro.2016.03.025.

Markowicz, F., Król, G., \& SzymanskaPulikowska, A. (2019). Biodegradable package - Innovative purpose or source of the problem. Journal of Ecological Engineering, 20(1), 228-237. https://doi. org/10.12911/22998993/94585

Markowicz, F., \& Szymańska-Pulikowska, A. (2019). Analysis of the possibility of environmental pollution by composted biodegradable and oxobiodegradable plastics. Geosciences (Switzerland), 9(11). https://doi.org/10.3390/ geosciences 9110460

Milliati. R., \& Estiyono, A. (2019). Pengembangan Material Komposit Serat Nanas sebagai Desain Produk Furniture. Jurnal Sains dan Seni, Vol.7. No.2. hal i50-154. ITS. Doi: 10.12962/ j23373520.v7i2.35318

Milman, A. (2007). 'Theme Park Tourism and Management Strategy'. In Tourism Management: Analysis, Behaviour and Strategy. Book Chapter. CAN International, Wallingford, UK. pp.218231. Doi: $10.1079 / 9781845933234.0218$

Mistiani, N., Prasetyo Ardi, R., \& Listyorini, H. (2018). Development Tourism Village Strategy of Samiran as a Creative Tourism Model in Central Java, 
Atlantis Press : Proceedings of the 2nd International Conference on Tourism, Gastronomy, and Tourist Destination (ICTGTD2018): Proceeding Advancesin Economics, Business and Management Research. Volume 52. Pp.72-78. Doi: 10.2991/ictgtd-18.2018.10.

Mueller-Roterberg, Christian. (2018). Handbook of Design Thingking, Hochschule Ruhr West.

Panda, K.K., Das, A.B,.\& Panda, B.B. (2009). Use and Variation of Pandanus Tectorius Parkinson along the Coastline of Orissa, India. In Genetic Resources and Crop Evaluation. Volume 56, pp. 629-637. Doi: 10.1007/s10722-008-93902

Przybytek, A., Sienkiewicz, M., KucińskaLipka, J., \& Janik, H. (2018). Preparation and characterization of biodegradable and compostable PLA/ TPS/ESO compositions. Industrial Crops and Products. Doi : 10.1016/j. indcrop.2018.06.016

Putra, I Nyoman Darma. (2018). “workshop Destinasi Pariwisata Budaya di Bali", diselenggarakan Kementerian Pariwisata, Sanur, Bali, 15 Mei 2018.

Putra, T. (2019). A Review on Penta Helix Actors in Village Tourism Development an Management. Journal of Businesson Hospitality and Tourism (JBHOST). Vol.5. Issue 01. Pp.63-75. Doi. 10.22334/ jbhost.v5i1.150

Riyanto, A., Respati, S.M.B., \& Syafa'at, i. (2019). Tegangan Pullout dan Perekaan Permukaan pada Serat Daun Pandan Duri (Pandanus Tectorius) - Resin Polyester. Jurnal Ilmiah Momentum. Vol.15. No.1. hal.70-78. Doi: 10.36499/ jim.v15i1.2664

Sari, N. (2008). Peluang Pengembangan Usaha Ekowosata Kawasan Wisata Alam Sangkima si Taman Nasional Kutai. Jurnal Analisi Kebijakan Kehutanan. Vol.5. No (3), hal. 153-164.

Schianetz, K., \& Kavanagh, L. (2008). Sustainability Indicators for Tourism Destinations: a Complex Adaptive System Approach Using System Indicator Systems. Journal of
Sustainable Tourism. Volume 16. No 6, pp 601-628. Doi: 10.2167/jost766.0

Setiawan, W.L. (2017). Diffusion of Innovation of Creative Industry Values on the Tenants of Sragen Techno Park Trough Business Incubator Model. European Journal of Economics and Business Studies. Volume 3. Issue 2. pp. 4-56. Doi: 10.26417/ejes.v8i1.p48-56

Siswanto, A., \& Moeljadi, M. (2015). Ecotourism Development Strategy Baluaran Nastional Park in the Regency of Situbondo, East Java, Indonesia. International Journal of Evaluation and Research in Education (IJERE).Vol. 4. No. 4. pp.185-195. Doi: 10.11591/ijere. v4i4.4510

Smith, N.R. (2019). One Village, One Product: Agro-industrial Village Corporatism in Contemporery China. Journal of Agrarian Change.Vol.19. Issue 2. pp.249-269. Doi: 10.1111/joac.12301.

Sofyan, A. N., Sofianto, K., Sutirman, M., \& Suganda, D. (2018). Kerajinan Payung Geulis sebagai Kearifan Lokal Tasikmalaya. Panggung. Vol 28, No.4 hal.388-402 https://doi.org/10.26742/ panggung.v28i4.708

Stone, B.C. (1988). Notes on the Genus Pandanus (Pandanaceae) in Tahiti. Botanical Journal of the Linnean Society. Vol.97. Issue 1. May1988. Pp.33-48. Doi: 10.1111/j.1095-8339.1988. tb01685.x

Subekti, P.,Perbawasari, S., \& Komala, L. (2017). The Role of Kompepar Pangandaran in Developing Pangandaran Becoming National Tourism Destination. Annual Conference of Communication, Media an Culture (ACCOMAC).Proceeding. Vol.1. No.1. Juli, 2017. pp.121-124.

Suci, Yuli Rahmini. (2017). Perkembangan UMKM (Usaha Mikro Kecil Menengah) di Indonesia, Jurnal Ilmiah Cano Ekonomos, Vol 6, No.1, pp 51-58.

Supriatna, F.F., (2019). Relokasi Pedagang Kaki Lima: Strategi Coping dalam Meningkatkan Kualitas Pariwisata di Pantai Pangandaran. WELFARE: Jurnal Ilmu Kesejahteraan Sosial, Vol. 8. Issue 1. pp 16-35. 
Supriyatna, A., \& Solihin, Y. (2018). Pengembangan Komposiit Epoxy Berpenguat Serat Nanas untuk Aplikasi Interior Mobil. Teknobiz: Jurnal Ilmiah Program Studi Magister Teknik Mesin. Vol.8 No.2 pp. 88-93. Doi: 10.35814/ teknobiz.v8i2.900

Suryajaya, Marthi.(2016). Sejarah Estetika, Jakarta: penerbit Gang Kabel.

Tisdell, C.,\& Wilson, C. (2002). Ecotourism for the Survival of Sea Turtles and other wildlife. Biodiversity and Conservation. Vol.11. pp.1521-1538. Doi: 10.1023/A:1016833300425

Tresna, P.W., Chan, A., \& Herawaty, T. (2019). City Banding of Pangandaran District as City of Tourism. Jurnal Pemikiran dan Penelitian Administrasi Bisnis dan Kewirausahaan. Vol.4 No. 1. pp.63-71. Doi.10.24198/adbispreneur.v4i1.19813.

Tyl, B., Lizarralde, I., \& Allasi, R. (2015). Local Value Creation and Eci-design: a New Paradigm. In Procedia CIRP. Vol.30. pp.155-160. Doi: 10.1016/j. procir.2015.02.024.

Vigneshwaran, G.V., Jenish, I., \& Sivasubramanian, R. (2014). Design, Fabrication and Experimental Analysis of Pandanus Fibre Reinforced Polyester Composite. In Advanced Material Research. Volumes (984-985). pp.253256. Doi: 10.4028/www.scientific.net/ AMR.984-985.253.

Wang, S. M. (2018). Effects of Interactive Marketing on Value Co-creation in Cultural Tourism. Journal of Interdisciplinary Mathematics. Volume 21, Issue, pp. 489-497. Doi: 10.1080/09720502.2017.1420578 